\title{
Evaluation of Antimicrobial Activity of Cinnamaldehyde against Carbapenem-Resistant Acinetobacter baumannii Nosocomial Isolates
}

\author{
Ana Jessyca Alves Morais ${ }^{1}$, Izabelly Linhares Ponte Brito ${ }^{2}$, \\ Xhaulla Maria Quariguasi Cunha Fonseca ${ }^{3}$, Vicente de Paulo Teixeira Pinto ${ }^{1,2}$ \\ and Francisco Cesar Barroso Barbosa ${ }^{2 *}$
}
${ }^{1}$ Postgraduate Program in Biotechnology, ${ }^{2}$ Postgraduate Program in Health Sciences, Federal University of Ceará, Sobral, CE, Brazil
${ }^{3}$ Postgraduate Program in Medical Microbiology, Federal University of Ceará, Fortaleza, CE, Brazil

*Corresponding author

\section{A B S T R A C T}

\section{Keywords}

Acinetobacter baumannii,

Cinnamaldehyde,

Multidrug-

resistance,

Nosocomial

infection, Teaching

hospital

Article Info

Accepted:

07 April 2019

Available Online:

10 May 2019

\begin{abstract}
The emergent and rapid spread of carbapenem-resistant $A$. baumannii isolates poses a severe threat to public health. Thus, the growing interest in new therapies based on natural products is the basic and primary source for the emergence of new antimicrobials. The aim of this study was to evaluate the antimicrobial activity of cinnamaldehyde against carbapenem-resistant $A$. baumannii nosocomial strains $(\mathrm{n}=47)$ isolated from patients in four teaching hospitals at Ceará, Brasil. Phenotypic identification and susceptibility to different antimicrobials were determined by VITEK ${ }^{\circledR 2}$, additionally gene blaOXA-51 was amplified by PCR on all presumptively identified as A. baumannii and the clinical characteristics were analyzed. The MIC of the cinnamaldehyde was performed according to microdilution methodology in standard 96-well polystyrene plates, according to the CLSI recommendations and MBC was determined. The MIC ranged from 125 to 500 $\mu \mathrm{g} / \mathrm{mL}($ Mean $=210.93 \pm 58.55$ ) and the MBC for most isolates was $250 \mu \mathrm{g} / \mathrm{mL}$ (Mean $=$ $510.41 \pm 230.39$ ). Bloodstream was the most frequent isolation site, and most of the strains were isolated from Intensive Care Units. These data demonstrated a potent inhibitory and bactericidal effect of cinnamaldehyde against carbapenem-resistant A.baumannii nosocomial strains, suggesting the prospection of this compound for the development of a new antibacterial substance.
\end{abstract}

\section{Introduction}

The multidrug-resistant Acinetobacter baumannii (MDRB) have emerged worldwide as an important cause of hospital infections, exhibiting high rates of resistance (Lee et al.,
2017; Raro et al., 2017). A. baumannii infections occur in Intensive Care Units (ICUs), where they are commonly found to be a cause of pneumonia associated with mechanical ventilation, urinary tract infections, secondary meningitis, and 
bacteremia (Clark et al., 2016; Maragakis and Perl, 2008). These microorganisms have great ability to increase their regulation of antimicrobial resistance or to acquire resistance determinants ( $\mathrm{Hu}$ et al., 2016). Furthermore, $A$. baumannii is prone to develop biofilms on solid surfaces, including medical devices (Gayoso et al., 2014). Thus, the combination of the vast resistance mechanisms of $A$. baumannii species and their survival capacity in the hospital environment make them potential nosocomial pathogens (Montagu et al., 2016).

These microorganisms are considered opportunistic pathogens because they are isolated from immunosuppressed patients who have undergone major surgeries, antibiotic therapies, burns, use of devices and mainly mechanical ventilation, and can cause severe infections (Doi et al., 2015).

A. baumannii has been shown to develop resistance to several classes of antibiotics, including aminoglycosides, cephalosporins, carbapenems, tigecycline, and colistin (Bonnin et al., 2013). One an important mechanism of resistance is the presence of $\beta$ lactamases, including oxacillinases, which are enzymes capable of hydrolyzing carbapenems, imipenem, and meropenem, important antimicrobials as a therapeutic resource against resistant multidrug bacteria (Nordmann et al., 2012). Carbapenems are important antibiotics to treat A. baumannii because they are highly efficacious and have low toxicity (Evans et al., 2013). However, the increasing prevalence of carbapenemresistant A. baumannii, particularly in the last two decades, has been of immense concern such that carbapenem-resistant $A$. baumannii is now listed as the top priority pathogen in urgent need of new antimicrobials by the World Health Organization in February 2017 (World Health Organization, 2017).

In this context, it is necessary to search for new therapeutic approaches, among which the prospection of compounds is that have activity against multiresistant bacteria, such as compounds and molecules isolated from plants.

Essential oils and their secondary metabolites, since the Middle Ages, are used as bactericides, insecticides, antiseptics, and fungicides. Due to its multiple properties, these compounds are currently widely used in the pharmaceutical and food industries, cosmetics, medical equipment, among others (Bakkali et al., 2008; Perricone et al., 2015).

Studies have shown that cinnamaldehyde is the major compound $(83.6 \%)$ among components of cinnamon oils (Yeh et al., 2013). In the literature, there are reports of the antibacterial activity of cinnamaldehyde against gram-positive and gram-negative bacteria, however, studies of the activity of this substance against multidrug-resistant microorganisms are scarce. Therefore, the aim of this study was to evaluate the antimicrobial activity of cinnamaldehyde against $A$. baumannii nosocomial strains resistant to carbapenems isolated from patients in different teaching hospitals in the State of Ceará, Brazil.

\section{Materials and Methods}

The present study was conducted according to the Declaration of Helsinki, and the protocol was approved by the Institutional Ethics Committee of the State University of Vale de Acaraú, Sobral, Ceará, Brazil (Protocol $\left.n^{\circ} 1,843,504\right)$.

\section{Bacterial strains}

Carbapenem-resistant A. baumannii strains analyzed in this study were part of the database of the Microbiology and Parasitology Laboratory of the FAMED 
(UFC/ Sobral), which were collected during the period from November 2016 to April 2017, from Santa Casa de Misericórdia de Sobral (SCMS), Hospital Geral Cesar Cals (HGCC), Hospital Geral de Fortaleza (HGF), and from Hospital Universitário Walter Cantídio (HUWC). Phenotypic identification and susceptibility to antimicrobials were determined by the VITEK®2 automated system (BioMérieux, Marcy-l'Etoile, France) in the microbiology laboratories of these hospitals.

Phenotypic confirmation of the strains by detection of bla ${ }_{\text {OXA-51 }}$ gene

A. baumannii presents the natural occurrence of intrinsic carbapenemases genes such as the bla $_{\text {OXA-51 }}$ gene (Turton et al., 2006). Therefore, the nosocomial species of $A$. baumannii resistant to carbapenems were analyzed for the detection of bla $a_{\text {OXA-51 }}$ gene by Polymerase Chain Reaction (PCR). The primers and protocols previously described by Ma et al., (2015) were used to amplify the bla $a_{\text {OXA-51 }}$ gene. The sequence of the fragments that were amplified, the size of the amplicons and the annealing temperature is described in Table 1.

\section{Preparation of cinnamaldehyde solution}

The cinnamaldehyde was purchased from Sigma (purity $\geq 95 \%$; BCD: 1345 ; CAS: $104-$ 55-2). Solubilized in 5\% DMSO and diluted in Brain Heart Infusion (BHI) medium (KASVI, Curitiba, Brazil) to obtain a concentration of $2,000 \mu \mathrm{g} / \mathrm{mL}$. Starting from this concentration, a serial dilution was performed in 96-well plate with an initial concentration of $1,000 \mu \mathrm{g} / \mathrm{mL}$.

\section{Preparation of bacterial suspension}

Bacteria were reactivated from the inoculation of $50 \mu \mathrm{L}$ of a culture stocked in a test tube containing $5 \mathrm{~mL}$ of BHI broth (KASVI,
Curitiba, Brazil), then incubated at $37^{\circ} \mathrm{C}$ for $18 \mathrm{~h}$ in aerobic conditions.

After this period, the bacterial suspensions were inserted into a 96-well plate and the absorbance reading was performed, where the concentration was adjusted by spectrophotometer $($ Abs $=620 \mathrm{~nm})$ at $10^{8}$ $\mathrm{CFU} / \mathrm{mL}$. These bacterial suspensions with $10^{8} \mathrm{CFU} / \mathrm{mL}$ were used to determinate the minimum inhibitory concentration (MIC) and minimum bactericidal concentration (MBC).

\section{Minimum Inhibitory Concentration (MIC)}

The determination of the minimum inhibitory concentration (MIC) of cinnamaldehyde was performed according to microdilution methodology in standard 96-well polystyrene plates according to the M7-A 10th edition, Methods for Dilution Antimicrobial Susceptibility Tests for Bacteria That Grow Aerobically, according to Clinical and Laboratory Standards Institute (CLSI, 2018). Subsequently, the plates were analyzed by the Elisa reader (BIO Trak II - Plate Reader®).

The test was performed on eight replicates for the same microorganism and the concentrations from $1,000 \mu \mathrm{g} / \mathrm{mL}$ to 1.95 $\mu \mathrm{g} / \mathrm{mL}$ were analyzed. In the last column of the 96-well plate were the controls: negative (bacterial suspension + medium), turbidity (medium + test substance) and control of contamination of the medium.

After completing the plate assembly, an initial reading (zero time) was performed by an ELISA reader (BIO Trak II - Plate Reader®) with a wavelength of $620 \mathrm{~nm}$.

Then the microplate was incubated at $37^{\circ} \mathrm{C}$ for 24 hours and after that period a new reading was performed to evaluate bacterial growth through turbidity with the aid of the ELISA. 


\section{Minimum bactericidal concentration (MBC)}

The determination of the minimum bactericidal concentration (MBC) was performed using the method proposed by Courvalin et al., (1995). After determination of the MIC, $10 \mu \mathrm{L}$ of the wells where there was no visible microbial growth were transferred for Petri dishes containing Muller Hinton Agar medium (KASVI, Curitiba, Brazil), then incubated at $37^{\circ} \mathrm{C}$ for 24 hours in the aerobic growth greenhouse. MBC was considered the lowest concentration of cinnamaldehyde where there was no cell growth on the surface of the inoculated agar (99.9\% of microbial death).

\section{Statistical analysis}

Statistical analyzes were performed using GraphPad® Prism software version 5.04 for Windows (GraphPad Software, San Diego California USA). The level of significance was $0.01(p \leq 0.01)$. The difference between replicate means was verified using the Oneway ANOVA with Bonferroni post-test.

\section{Results and Discussion}

Table 2 shows the distribution of 47 nosocomial strains of A. baumannii isolated from patients in the four teaching hospitals surveyed per hospital unit, isolation site, and hospitalization sector.

It was observed that bloodstream was the most frequent isolation site, followed by tracheal aspirate and secretion from the surgical wound. Furthermore, most of the strains were isolated from Intensive Care Units, followed by clinical and surgical wards (Table 2).

Table 3 shows the results of the in vitro antimicrobial susceptibility profile of 47 nosocomial A. baumannii MDR against 16 antimicrobials of various classes, including $\beta$ lactams, glycylcyclines, quinolones, aminoglycosides, and polymyxins. Isolates showed different sensitivity profiles to clinically available antibiotics, but all presented resistance to carbapenems and sensitivity to colistin. Furthermore, 8 (17.0\%) isolates were resistant or intermediately susceptible to tigecycline. So, the minimum inhibitory concentrations were determined by a broth microdilution technique for isolates resistant to tigecycline following the recommendations of the Clinical and Laboratory Standards Institute (CLSI, 2018).

The minimum inhibitory concentration (MIC) of cinnamaldehyde to the tested isolates ranged from 125 to $500 \mu \mathrm{g} / \mathrm{mL}$ (Mean = $210.93 \pm 58.55)$ and the minimum bactericidal concentration for most isolates was $250 \mu \mathrm{g} / \mathrm{mL}($ Mean $=510.41 \pm 230.39)$ (Table 4).

The alarming increase in antibiotic-resistant bacteria has led to many undesirable phenomena such as the failure of antimicrobial therapy and the frequency of infections by multiresistant microorganisms (Aelenei et al., 2016; Perez et al., 2017; Turton et al., 2006). In this regard, the identification of new natural substances with antimicrobial activity may be effective alternatives against these pathogens. Currently, the use of natural substances, especially essential oils (EOs) and their isolated substances are studied for the prevention and treatment of infections caused by MDR bacteria (Burt, 2004; Chouhan et al., 2017).

A. baumannii presents the natural occurrence of carbapenemases genes intrinsic to this species (Turton et al., 2006). The first report of this genetic event presented the bla $a_{\text {OXA-51 }}$ gene. Subsequently, the presence of variants 
similar to this gene has been reported, these being named bla $a_{\text {OXA-51-LIKE genes (Turton et }}$ al., 2006). Usual phenotypic examinations in the laboratory routine are often ineffective in identifying Acinetobacter sp. when not associated with molecular tests, such as PCR (Kooti et al., 2015). Thus, it is necessary to use another test as confirmation criterion showing reliable results for the therapeutic choice. In this search, the confirmation of the phenotypic identification obtained by the automated system the VITEK® 2 was obtained by the detection of the bla $a_{\text {OXA-51 }}$ gene, validating all the results provided by the equipment.

In this study, A. baumanni was more isolated from the bloodstream and tracheal aspirate, often associated with patients admitted to intensive care units (ICUs). These data corroborate findings in the literature that this microorganism is responsible for increasingly severe outbreaks of infections and the incidence of nosocomial infections in the bloodstream caused by this pathogen is becoming more frequent (Bianco et al., 2016). Infections by A. baumannii are more frequent in ICUs, where they are commonly found to be a cause of ventilator-associated pneumonia, urinary tract infections, meningitis, and bacteremia (Dahdouh et al., 2017; Li et al., 2013).

Regarding the sensitivity profile, the isolates analyzed presented different sensitivity patterns. Colistin and tigecycline have been shown to be the most effective antimicrobials; these results are relevant with other studies demonstrating that these drugs may be the best therapeutic option for the treatment of patients with carbapenem-resistant A.baumannii infections (Castilho et al., 2017; Dahdouh et al., 2017; El-shazly et al., 2015). However, in this study almost $20 \%$ of the isolates analyzed were resistant or intermediate susceptible to tigecycline. The resistance rate of this microorganism to imipenem and meropenem, increased from $31 \%$ in 2005 to $62.4 \%$ in 2014 and from $39 \%$ in 2005 to $66.7 \%$ in 2014 , respectively ( $\mathrm{Hu}$ et al., 2016).

It should be noted that the worldwide emergence of multidrug-resistant $A$. baumannii reduced the number of antibiotics available against this pathogen, including resistance to $\beta$-lactams, fluoroquinolones, tetracyclines, and aminoglycosides (Cai et al., 2012). Thus, bacterial resistance to the available antibiotics induced the search for new therapies and strategies aimed at decreasing the development of MDR bacteria (Ferro et al., 2016). Importantly, in this study cinnamaldehyde showed significant antimicrobial activity against clinical isolates of $A$. baumannii that presented a phenotype of resistance to carbapenems, which are the most effective antibiotics for the treatment of infections caused by this pathogen.

In the literature there are reports of the toxicity of this substance, providing data from in vivo studies suggesting that cinnamaldehyde is safe when administered orally in a single dose $(2,220 \mathrm{mg} / \mathrm{kg})$ or for up to 2 years $(550 \mathrm{mg} / \mathrm{kg} /$ day $)$. It is worth noting that the rate of excretion of cinnamaldehyde after $24 \mathrm{~h}$ of administration varies from 70 to $98 \%$ in rodents, depending on the route of administration, and reaches $100 \%$ within $8 \mathrm{~h}$ when administered orally to healthy human volunteers (Cocchiara et al., 2015). Cinnamaldehyde has been identified and utilized as a non-toxic, food-grade antimicrobial agent. It is generally regarded as safe by the US Food and Drug Administration (USFDA, 2017). Only high concentrations for prolonged exposures have been shown to cause detrimental physiological changes in mammals (Hooth et al., 2004). In this study, cinnamaldehyde presented a MIC of 250 $\mu \mathrm{g} / \mathrm{mL}$ for $70.2 \%$ and an $\mathrm{MBC}$ of the same 
value for $23.5 \%$ of the analyzed strains, these data were statistically significant and presenting lower inhibitory concentrations than those observed by Guerra et al., 2012) that evaluated the antimicrobial activity of cinnamon oil against Acinetobacter sp. MDR.
However, they analyzed the MIC of the volatile oil, obtaining a MIC of $625 \mu \mathrm{g} / \mathrm{mL}$ for $71 \%$ of the strains analyzed and an MBC that ranged from $2,500 \mu \mathrm{g} / \mathrm{mL}$ to 1,250 $\mu \mathrm{g} / \mathrm{mL}$.

Table.1 Primers for amplification of the blaOXA-51 gene

\begin{tabular}{|l|c|c|c|}
\hline Primer & Sequence (5'-3') & $\begin{array}{c}\text { Amplicon } \\
(\mathbf{p b})\end{array}$ & $\begin{array}{l}\text { Anellament } \\
\left.\text { temperature } \mathbf{(}^{\mathbf{0}} \mathbf{C}\right)\end{array}$ \\
\hline bla $_{\text {OXA-51 }} \mathbf{F}$ & Amplification of bla $_{\text {OXA-51 }}$ & 353 & $53^{\circ} \mathrm{C}$ \\
\hline bla $_{\text {OXA-51 }} \mathbf{R}$ & TGG ATT GCA CTT CAT CTT GG & & \\
\hline
\end{tabular}

Table.2 Distribution of A. baumannii nosocomial strains per hospital unit, isolation site, and hospitalization sector*

\begin{tabular}{|l|c|c|}
\hline & n & \% \\
\hline Microorganism & & \\
\hline Acinetobacter baumannii & 47 & 100.0 \\
\hline Hospital unit & & \\
\hline SCMS & 12 & 25.5 \\
\hline HGCC & 12 & 25.5 \\
\hline HGF & 12 & 25.5 \\
\hline HUWC & 11 & 23.4 \\
\hline Isolation site & & \\
\hline Blood & 15 & 32.0 \\
\hline Tracheal aspirate & 11 & 23.4 \\
\hline Secretion & 8 & 17.0 \\
\hline Urine & 5 & 10.6 \\
\hline Catheter tip & 2 & 4.2 \\
\hline Tissue fragmente & 2 & 4.2 \\
\hline Alveolar bronchial lavage & 2 & 4.2 \\
\hline Nasal swab & 1 & 2.1 \\
\hline Ulcer tissue & 1 & 2.1 \\
\hline Hospitalization sector & & \\
\hline UTI & 31 & 65.9 \\
\hline Clinical and surgical wards & 12 & 25.5 \\
\hline Neurology & 2 & 4.2 \\
\hline Traumato orthopedics & 2 & 4.2 \\
\hline
\end{tabular}

*Reports generated by automated identification system Gram-negative bacillus GN, VITEK® 2; BioMérieux, France. 
Table.3 The antimicrobial resistance profiles of $A$. baumannii nosocomial strains from the four teaching hospitals analyzed

\begin{tabular}{|c|c|c|c|c|c|c|c|c|}
\hline \multirow[t]{2}{*}{ Antimicrobial } & \multicolumn{2}{|c|}{ Resistant } & \multicolumn{2}{|c|}{ Sensitive } & \multicolumn{2}{|c|}{ Intermediate } & \multicolumn{2}{|c|}{ No tested } \\
\hline & $\mathbf{n}$ & $\%$ & $\mathbf{n}$ & $\%$ & $\mathbf{n}$ & $\%$ & $\mathbf{n}$ & $\%$ \\
\hline Amikacin & 23 & 48.9 & 10 & 21.2 & 3 & 6.3 & 11 & 23.4 \\
\hline Ampicillin & 46 & 97.8 & 0 & 0.0 & 1 & 2.1 & 0 & 0.0 \\
\hline Ampicillin sulbactan & 23 & 48.9 & 2 & 4.2 & 21 & 44.6 & 1 & 2.1 \\
\hline Cefepime & 42 & 89.3 & 1 & 2.1 & 4 & 8.5 & 0 & 0.0 \\
\hline Cefoxitin & 43 & 91.4 & 1 & 2.1 & 2 & 4.2 & 1 & 2.1 \\
\hline Ceftazidime & 45 & 95.7 & 0 & 0.0 & 1 & 2.1 & 1 & 2.1 \\
\hline Ceftriaxone & 41 & 87.2 & 0 & 0.0 & 6 & 12.7 & 0 & 0.0 \\
\hline Cefuroxime & 47 & 100 & 0 & 0.0 & 0 & 0.0 & 0 & 0.0 \\
\hline Cefuroxime axetil & 47 & 100 & 0 & 0.0 & 0 & 0.0 & 0 & 0.0 \\
\hline Ciprofloxacin & 44 & 93.6 & 3 & 6.3 & 0 & 0.0 & 0 & 0.0 \\
\hline Colistin & 0 & 0.0 & 47 & 100 & 0 & 0.0 & 0 & 0.0 \\
\hline Gentamicin & 24 & 51 & 18 & 38.2 & 5 & 10.6 & 0 & 0.0 \\
\hline Imipenem & 47 & 100 & 0 & 0.0 & 0 & 0.0 & 0 & 0.0 \\
\hline Meropenem & 47 & 100 & 0 & 0.0 & 0 & 0.0 & 0 & 0.0 \\
\hline Piperacillin/tazobactam & 47 & 100 & 0 & 0.0 & 0 & 0.0 & 0 & 0.0 \\
\hline Tigecycline & 3 & 6.3 & 38 & 80.8 & 5 & 10.6 & 1 & 2.1 \\
\hline
\end{tabular}

Data expressed as absolute frequency and percentage.

Table.4 Minimal inhibitory concentration (MIC) and minimum bactericidal concentration (MBC) of cinnamaldehyde against 47 A. baumannii nosocomial isolates

\begin{tabular}{|c|c|c|c|}
\hline Nosocomial strains & MIC & MBC & Hospital Unit \\
\hline AB1LAMP & $250 \mu \mathrm{g} / \mathrm{mL}$ & $500 \mu \mathrm{g} / \mathrm{mL}$ & SCMS \\
\hline AB2LAMP & $250 \mu \mathrm{g} / \mathrm{mL}$ & $250 \mu \mathrm{g} / \mathrm{mL}$ & SCMS \\
\hline AB5LAMPR & $250 \mu \mathrm{g} / \mathrm{mL}$ & $500 \mu \mathrm{g} / \mathrm{mL}$ & SCMS \\
\hline AB10LAMPR & $125 \mu \mathrm{g} / \mathrm{mL}$ & $500 \mu \mathrm{g} / \mathrm{mL}$ & SCMS \\
\hline AB12LAMPR & $125 \mu \mathrm{g} / \mathrm{mL}$ & $250 \mu \mathrm{g} / \mathrm{mL}$ & SCMS \\
\hline AB16LAMPR & $125 \mu \mathrm{g} / \mathrm{mL}$ & $250 \mu \mathrm{g} / \mathrm{mL}$ & SCMS \\
\hline AB18.1LAMP & $250 \mu \mathrm{g} / \mathrm{mL}$ & $1000 \mu \mathrm{g} / \mathrm{mL}$ & SCMS \\
\hline AB18.2LAMP & $125 \mu \mathrm{g} / \mathrm{mL}$ & $250 \mu \mathrm{g} / \mathrm{mL}$ & SCMS \\
\hline AB20LAMPR & $250 \mu \mathrm{g} / \mathrm{mL}$ & $500 \mu \mathrm{g} / \mathrm{mL}$ & SCMS \\
\hline AB23LAMPR & $250 \mu \mathrm{g} / \mathrm{mL}$ & $500 \mu \mathrm{g} / \mathrm{mL}$ & SCMS \\
\hline AB25LAMPR & $250 \mu \mathrm{g} / \mathrm{mL}$ & $1000 \mu \mathrm{g} / \mathrm{mL}$ & SCMS \\
\hline AB35LAMPR & $250 \mu \mathrm{g} / \mathrm{mL}$ & $500 \mu \mathrm{g} / \mathrm{mL}$ & SCMS \\
\hline AB52LAMP & $125 \mu \mathrm{g} / \mathrm{mL}$ & $250 \mu \mathrm{g} / \mathrm{mL}$ & HGF \\
\hline AB57LAMP & $125 \mu \mathrm{g} / \mathrm{mL}$ & $500 \mu \mathrm{g} / \mathrm{mL}$ & HGF \\
\hline AB60LAMPR & $250 \mu \mathrm{g} / \mathrm{mL}$ & $500 \mu \mathrm{g} / \mathrm{mL}$ & HGF \\
\hline AB62LAMPR & $125 \mu \mathrm{g} / \mathrm{mL}$ & $500 \mu \mathrm{g} / \mathrm{mL}$ & HGF \\
\hline AB66LAMPR & $125 \mu \mathrm{g} / \mathrm{mL}$ & $500 \mu \mathrm{g} / \mathrm{mL}$ & HGF \\
\hline AB68LAMPR & $250 \mu \mathrm{g} / \mathrm{mL}$ & $250 \mu \mathrm{g} / \mathrm{mL}$ & HGF \\
\hline
\end{tabular}




\begin{tabular}{|c|c|c|c|}
\hline AB75LAMP & $125 \mu \mathrm{g} / \mathrm{mL}$ & $250 \mu \mathrm{g} / \mathrm{mL}$ & HGF \\
\hline AB78LAMP & $125 \mu \mathrm{g} / \mathrm{mL}$ & $500 \mu \mathrm{g} / \mathrm{mL}$ & HGF \\
\hline AB79LAMPR & $125 \mu \mathrm{g} / \mathrm{mL}$ & $500 \mu \mathrm{g} / \mathrm{mL}$ & HGF \\
\hline AB80LAMPR & $250 \mu \mathrm{g} / \mathrm{mL}$ & $250 \mu \mathrm{g} / \mathrm{mL}$ & HGF \\
\hline AB81LAMPR & $125 \mu \mathrm{g} / \mathrm{mL}$ & $1000 \mu \mathrm{g} / \mathrm{mL}$ & HGF \\
\hline AB125LAMPR & $250 \mu \mathrm{g} / \mathrm{mL}$ & $1000 \mu \mathrm{g} / \mathrm{mL}$ & HGF \\
\hline AB48LAMP & $125 \mu \mathrm{g} / \mathrm{mL}$ & $250 \mu \mathrm{g} / \mathrm{mL}$ & HGCC \\
\hline AB83LAMP & $250 \mu \mathrm{g} / \mathrm{mL}$ & $500 \mu \mathrm{g} / \mathrm{mL}$ & HGCC \\
\hline AB84LAMPR & $250 \mu \mathrm{g} / \mathrm{mL}$ & $500 \mu \mathrm{g} / \mathrm{mL}$ & HGCC \\
\hline AB87LAMPR & $250 \mu \mathrm{g} / \mathrm{mL}$ & $500 \mu \mathrm{g} / \mathrm{mL}$ & HGCC \\
\hline AB88LAMPR & $250 \mu \mathrm{g} / \mathrm{mL}$ & $500 \mu \mathrm{g} / \mathrm{mL}$ & HGCC \\
\hline AB90LAMPR & $250 \mu \mathrm{g} / \mathrm{mL}$ & $500 \mu \mathrm{g} / \mathrm{mL}$ & HGCC \\
\hline AB93LAMP & $250 \mu \mathrm{g} / \mathrm{mL}$ & $500 \mu \mathrm{g} / \mathrm{mL}$ & HGCC \\
\hline AB100LAMP & $250 \mu \mathrm{g} / \mathrm{mL}$ & $500 \mu \mathrm{g} / \mathrm{mL}$ & HGCC \\
\hline AB102LAMPR & $250 \mu \mathrm{g} / \mathrm{mL}$ & $1000 \mu \mathrm{g} / \mathrm{mL}$ & HGCC \\
\hline AB105LAMPR & $250 \mu \mathrm{g} / \mathrm{mL}$ & $500 \mu \mathrm{g} / \mathrm{mL}$ & HGCC \\
\hline AB108LAMPR & $250 \mu \mathrm{g} / \mathrm{mL}$ & $500 \mu \mathrm{g} / \mathrm{mL}$ & HGCC \\
\hline AB110LAMPR & $250 \mu \mathrm{g} / \mathrm{mL}$ & $1000 \mu \mathrm{g} / \mathrm{mL}$ & HGCC \\
\hline AB140LAMP & $125 \mu \mathrm{g} / \mathrm{mL}$ & $250 \mu \mathrm{g} / \mathrm{mL}$ & HUWC \\
\hline AB141LAMP & $250 \mu \mathrm{g} / \mathrm{mL}$ & $500 \mu \mathrm{g} / \mathrm{mL}$ & HUWC \\
\hline AB142LAMPR & $250 \mu \mathrm{g} / \mathrm{mL}$ & $500 \mu \mathrm{g} / \mathrm{mL}$ & HUWC \\
\hline AB143LAMPR & $250 \mu \mathrm{g} / \mathrm{mL}$ & $500 \mu \mathrm{g} / \mathrm{mL}$ & HUWC \\
\hline AB145LAMPR & $250 \mu \mathrm{g} / \mathrm{mL}$ & $500 \mu \mathrm{g} / \mathrm{mL}$ & HUWC \\
\hline AB146LAMPR & $250 \mu \mathrm{g} / \mathrm{mL}$ & $250 \mu \mathrm{g} / \mathrm{mL}$ & HUWC \\
\hline AB147LAMP & $250 \mu \mathrm{g} / \mathrm{mL}$ & $500 \mu \mathrm{g} / \mathrm{mL}$ & HUWC \\
\hline AB148LAMP & $250 \mu \mathrm{g} / \mathrm{mL}$ & $500 \mu \mathrm{g} / \mathrm{mL}$ & HUWC \\
\hline AB149LAMPR & $250 \mu \mathrm{g} / \mathrm{mL}$ & $1000 \mu \mathrm{g} / \mathrm{mL}$ & HUWC \\
\hline AB150LAMPR & $250 \mu \mathrm{g} / \mathrm{mL}$ & $500 \mu \mathrm{g} / \mathrm{mL}$ & HUWC \\
\hline AB151LAMPR & $250 \mu \mathrm{g} / \mathrm{mL}$ & $500 \mu \mathrm{g} / \mathrm{mL}$ & HUWC \\
\hline AB216 reference & $125 \mu \mathrm{gg} / \mathrm{Ml}$ & $250 \mu \mathrm{g} / \mathrm{mL}$ & - \\
\hline strain & & & \\
\hline
\end{tabular}

Regarding the antimicrobial activity of cinnamaldehyde, these results reinforce the data of literature $\mathrm{Li}$ et al., (2013) that demonstrate that the antimicrobial activity of cinnamon oil is due to cinnamaldehyde (Ooi et al., 2006). Studies that evaluated the in vitro antimicrobial activity of cinnamon oil using the fusion disc method against $A$. baumannii and Pseudomonas aeruginosa resistant to carbapenems demonstrated effective qualitative results and confirmed that the antibacterial action was due to its major component, cinnamaldehyde (Kaskatepe et al., 2016). However, no quantitative methods were used to measure MIC and MBC, as well as, the majority component was not tested against these pathogens alone. The antimicrobial effect of cinnamon oil was also demonstrated against Escherichia coli, Klebsiella pneumoniae, $P$. aeruginosa, Proteus vulgaris, Bacillus subtilis and Staphylococcus aureus species with MIC values ranging from 800 to $3,200 \mu \mathrm{g} / \mathrm{mL}$ (Prabuseenivasan et al., 2006). The antimicrobial potential of different essential oils was analyzed, among them the cinnamon oil, and the researchers demonstrated that cinnamon oil demonstrated greater efficacy than the others, and its antimicrobial action was attributed to the presence of cinnamaldehyde, revealing that it was the main constituent of cinnamon oil Prabuseenivasan et al., (2006), confirming the data of Baratta et al., (1998), Sleha et al., 
(2014) and Utchariyakiat et al., (2016) that also reported that cinnamaldehyde was the predominant active compound found in cinnamon oil.

Data in the literature report the antimicrobial activity of cinnamaldehyde against Staphylococcus aureus and Enterococcus faecalis with MDR phenotypes with MIC values ranging from $250 \mu \mathrm{g} / \mathrm{mL}$ to $500 \mu \mathrm{g} / \mathrm{mL}$ and $\mathrm{MBC}$ of $1,000 \mu \mathrm{g} / \mathrm{mL}$ (Chang et al., 2001; Shen et al., 2015; Utchariyakiat et al., 2016). Therefore, these results demonstrated a potent inhibitory and bactericidal effect of cinnamaldehyde against carbapenem-resistant A.baumannii nosocomial isolates. Thus, these data suggest the prospection of this compound for the development of a new antibacterial substance, either as a medicament or in new products destined to the final disinfection of hospital environments, being able to reduce hospitalization costs and be safe in its use.

\section{Funding information}

This study was financed in part by the Coordenação de Aperfeiçoamento de Pessoal de Nível Superior - Brasil (CAPES) - Finance Code 001 (granting the scholarship) and by Santa Casa de Misericórdia de Sobral (Edital DEPE 02/2017).

\section{References}

Aelenei, P., Miron, A., Trifan, A., Bujor, A., Gille, E., Aprotosoaie, A.C. 2016. Essential Oils and Their Components as Modulators of Antibiotic Activity Against Gram-Negative Bacteria. Medicines. 3: 19.

Bakkali, F., Averbeck, S., Averbeck, D., Idaomar, M. 2008. Biological effects of essential oils-a review. Food Chem Toxicol. 46: 446-475.

Baratta, M.T., Dorman, H.J., Deans, S.G., Figueiredo, A.C., Barroso, J.G.,
Ruberto, G. 1998. Antimicrobial and antioxidant properties of some commercial essential oils. Flav Fragr J. 13: 235-244.

Bianco, A., Quirino, A., Giordano, M., Marano, V., Rizzo, C., Liberto, M.C., Focà, A., Pavia, M. 2016. Control of carbapenem-resistant Acinetobacter baumannii outbreak in an intensive care unit of a teaching hospital in Southern Italy. BMC Infect Dis. 16: 747.

Bonnin, R.A., Nordmann, P., Poirel, L. 2013. Screening and deciphering antibiotic resistance in Acinetobacter baumannii: a state of the art. Expert Rev Anti Infect Ther. 11: 571-583.

Burt, S. 2004. Essential oils: their antibacterial properties and potential 374 applications in food - a review. Intl. J. Food Microbiol. 94: 223-253.

Cai, Y., Chai, D., Wang, R., Liang, B., Bai, N. 2012. Colistin resistance of Acinetobacter baumannii: clinical reports, mechanisms, and antimicrobial strategies. J Antimicrob Chemother. 67: 1607-1615.

Castilho, S.R.A., Godoy, C.S.M., Guilarde, A.O., Cardoso, J.L., André, M.C.P., Junqueira-Kipnis, A.P., Kipnis, A. 2017. Acinetobacter baumannii strains isolated from patients in intensive care units in Goiânia, Brazil: Molecular and drug susceptibility profiles. Plos One. 12: e0176790.

Chang, S.T., Chen, P.F., Chang, C.C. 2001. Antibacterial activity of leaf essential oils and their constituents from Cinnamomum osmophloeum. J Ethnopharmacol. 77: 123-127.

Chouhan, S., Sharma, k., Guleria, S. 2017. Antimicrobial Activity of Some Essential Oils-Present Status and Future Perspectives. Medicines. 4: 58.

Clark, N.M., Zhanel, G.G., Lynch, J.P. 2016. Emergence of antimicrobial resistance among Acinetobacter species: a global 
threat. Curr Opin Crit Care. 22: 491499.

CLSI. 2018. Performance Standards for Antimicrobial Susceptibility Testing: 28 th ed; Clinical and Laboratory Standards Institute, document Wayne, PA: Clinical and Laboratory Standards Institute.

Cocchiara, J., Letizia, C.S., Lalko, J., Lapczynski, A., Api, A.M. 2005. Fragrance material review on cinnamaldehyde. Food Chem. Toxicol. 43: 867-923.

Courvalin, P., Goldstein, F., Philippon, A., Sirot, J.L. 1985. Antibiogramme, Ed. MPC-Videom, Paris, France.

Dahdouh, E., Gómez-Gil, R., Pacho, S., Mingorance, J., Daoud, Z., Suárez, M. 2017. Clonality, virulence determinants, and profiles of resistance of clinical Acinetobacter baumannii isolates obtained from a Spanish hospital. PLoS One. 12: e0176824.

Doi, Y., Murray, G.L., Peleg, A.Y. 2015. Acinetobacter baumannii: evolution of antimicrobial resistance-treatment options. Respir. Crit. Care Med. 36: 8598.

El-shazly, S., Dashti, A., Vali, L., Bolaris, M., Ibrahim, A.S. 2015. Molecular epidemiology and characterization of multiple-drug-resistant (MDR) clinical isolates of Acinetobacter baumannii. Int J Infect Dis. 41: 42-49.

Evans, B.A., Hamouda, A., Amyes, S.G. 2013. The rise of carbapenem-resistant Acinetobacter baumannii. Curr Pharm Des.19: 223-38.

Ferro, T.A., Araújo, J.M., Dos Santos Pinto, B.L., Dos Santos, J.S., Souza, E.B., Da silva, B.L., Colares, V.L., Novais, T.M., Filho, C.M., Struve, C., Calixto, J.B., Monteiro-neto, V., Da silva, L.C., Fernandes, E.S. 2016. Cinnamaldehyde Inhibits Staphylococcus aureus Virulence Factors and Protects against
Infection in a Galleria mellonella Model. Front Microbiol. 7: 2052.

Gayoso, C.M., Mateos, J., Méndez, J.A., Fernández-Puente, P., Rumbo, C., Tomás, M., Martínez de Ilarduya, O., Bou, G. 2014. Molecular mechanisms involved in the response to desiccation stress and persistence in Acinetobacter baumannii. J Proteome Res. 13:460 476.

Guerra, F.Q.S., Mendes, J.M., Oliveira, W.A., Rodrigues, L.A.S., Santos, B.H.C., Lima, E.O. 2012. Chemical composition and antimicrobial activity of Cinnamomum zeylanicum Blume essential oil on multi-resistant Acinetobacter spp. strains. Journal of Biology and Pharmacy. 1: 62-68.

Hooth, M.J., Sills, R.C., Burka, L.T., Haseman, J.K., Witt, K.L., Orzech, D.P., Fuciarelli, A.F., Graves, S.W., Johnson, J.D., Bucher, J.R. 2004. Toxicology and carcinogenesis studies of microencapsulated transcinnamaldehyde in rats and mice. Food Chem Toxicol. 42: 1757-1768.

Hu, F.P., Guo, Y., Zhu, D.M., Wang, F., Jiang, X.F., Xu, Y.C., Zhang, X.J., Zhang, C.X., Ji, P., Xie, Y., Kang, M., Wang, C.Q., Wang, A.M., Xu, Y.H., Shen, J.L., Sun, Z.Y., Chen, Z.J., Ni, Y.X., Sun, J.Y., Chu, Y.Z., Tian, S.F., Hu, Z.D., Li, J., Yu, Y.S., Lin, J., Shan, B., Du, Y., Han, Y., Guo, S., Wei, L.H., Wu, L., Zhang, H., Kong, J., Hu, Y.J., Ai, X.M., Zhuo, C., Su, D.H., Yang, Q., Jia, B., Huang, W. Resistance trends among clinical isolates in China reported from CHINET surveillance of bacterial resistance, 2005-2014. 2016. Clin Microbiol Infect. 22 Suppl 1: S914.

Kaskatepe, B., Kiymaci, M.E., Suzuki, S., Erdem, S.A., Cesur, S., Yildiz, S. 2016. Antibacterial effects of cinnamon oil against

carbapenem-resistant 
nosocomial Acinetobacter baumannii and Pseudomonas aeruginosa isolates. Industrial Crops and Products. 81: 191-194.

Kooti, S., Motamedifar, M., Sarvari, J. 2015. Antibiotic Resistance Profile and Distribution of Oxacillinase Genes Among Clinical Isolates of Acinetobacter baumannii in Shiraz Teaching Hospitals, 2012 - 2013. Jundishapur Journal of Microbiology. 8: e20215.

Lee, C.R., Lee, J.H., Park, M., Park, K.S., Bae, I.K., Kim, Y.B., Cha, C.J., Jeong, B.C., Lee, S.H. 2017. Biology of Acinetobacter baumannii: Pathogenesis, antibiotic resistance mechanisms, and prospective treatment options. Front. Cell. Infect. Microbiol. 7:55.

Li, Y., Kong, D., Wu, H. 2013. Analysis and evaluation of essential oil components of cinnamon barks using GC-MS and FTIR spectroscopy. Ind Crop Prod. 41: 269-78.

Ma, Z., Zhou, L.Q., Wang, H., Luo, L. 2015. Investigation on the genomic diversity of OXA from isolated Acinetobacter baumannii. Int J Clin Exp Med. 8: 4429-4432.

Maragakis, L.L., Perl, T.M. 2008. Acinetobacter baumannii: epidemiology, antimicrobial resistance, and treatment options. Clin Infect Dis. 46: 1254-1263.

Montagu, A., Joly-Guillou, M.L., Rossines, E., Cayon, J., Kempf, M., Saulnier, P. 2016. Stress Conditions Induced by Carvacrol and Cinnamaldehyde on Acinetobacter baumannii. Frontiers in Microbiology. 7: 1133.

Nordmann, P., Poirel, L., Dortet, L. 2012. Rapid detection of carbapenemaseproducing Enterobacteriaceae. Emerging Infectious Diseases. 18: 1503-1507.

Ooi, L.S.M., Li, Y., Kam, S.L., Wang, H.,
Wong, E.Y.L., Ooi, V.E.C. 2006. Antimicrobial activities of cinnamon oil and cinnamaldehyde from the Chinese medicinal herb Cinnamomum cassia blume. Am. J. Chin. Med. 34: 511-522.

Perricone, M., Arace, E., Corbo, M.R., Sinigaglia, M., Bevilacqua, A. 2015. Bioactivity of essential oils: a review of their interaction with food components. Front Microbiol. 6: 76.

Perez, F., Hujer, A.M., Hujer, K.M., Decker, B.K., Rather, P.N., Bonomo, R.A. 2017. Global challenge of multidrug-resistant Acinetobacter baumannii. Antimicrob Agents Chemother. 51: 3471-3484.

Prabuseenivasan, S., Jayakumar, M., Ignacimuthu, S. 2006. IN vitro antibacterial activity of some plant essential oils. BMC Complement Altern Med. 6: 39.

Raro, O.H.F., Gallo, S.W., Ferreira, C.A.S., Oliveira, S.D. 2017. Carbapenemresistant Acinetobacter baumannii contamination in an intensive care unit. Rev Soc Bras Med Trop. 50: 167-172.

Shen, S., Zhang, T., Yuan, Y., Lin, S., Xu, J., Ye, H. 2015. Effects of cinnamaldehyde on Escherichia coli and Staphylococcus aureus membrane. Food Control. 47: 196-202.

Sleha, R., Mosio, P., Vydrzalova, M., Jankowski, A., Bostikova, V., Mazurova, J. 2014. In vitro antimicrobial activities of cinnamon bark oil, anethole, carvacrol, eugenol and guaiazulene against Mycoplasma hominis clinical isolates. Biomed Pap Med Fac Univ Palacky Olomouc Czech Repub. 158: 208-211.

Turton, J.F., Woodford, N., Glover, J., Yarde, S., Kaufmann, M.E., Pitt, T.L. 2006. Identification of Acinetobacter baumannii by detection of the blaOXA51-like carbapenemase gene intrinsic to this species. J Clin Microbiol. 44: 29742976. 
United States Food and Drug Administration (USFDA), 2017. Available from http://www.accessdata.fda.gov/scripts/c $\mathrm{drh} / \mathrm{cfdocs} / \mathrm{cfcfr} / \mathrm{CFRSearch.cfm?fr=18}$ 2.60. Code of Federal Regulations title 21, 3. Accessed Feb. 23, 2018.

Utchariyakiat, I., Surassmo, S., Jaturanpinyo, M., Khuntayaporn, P., Chomnawang, M.T. 2016. Efficacy of cinnamon bark oil and cinnamaldehyde on antimultidrug resistant Pseudomonas aeruginosa and the synergistic effects in combination with other antimicrobial agents. BMC Complementary and Alternative Medicine. 16: 158.
World Health Organization, 2017. Available from: http://www.who.int/mediacentre /news/releases/2017/bacteriaantibiotics-needed/en/. Publishes List of Bacteria for Which New Antibiotics Are Urgently Needed. Geneva: World Health Organization, 2017. Accessed Feb. 23, 2018.

Yeh, H.F., Luo, C.Y., Lin, C.Y., Cheng, S.S., Hsu, Y.R., Chang, S.T. 2013. Methods for thermal stability enhancement of leaf essential oils and their main constituents from indigenous cinnamon (Cinnamomum osmophloeum). J Agric Food Chem. 61: 6293-6298.

\section{How to cite this article:}

Ana Jessyca Alves Morais, Izabelly Linhares Ponte Brito, Xhaulla Maria Quariguasi Cunha Fonseca, Vicente de Paulo Teixeira Pinto and Francisco Cesar Barroso Barbosa. 2019. Evaluation of Antimicrobial Activity of Cinnamaldehyde against Carbapenem-Resistant Acinetobacter baumannii Nosocomial Isolates. Int.J.Curr.Microbiol.App.Sci. 8(05): 434-445. doi: https://doi.org/10.20546/ijcmas.2019.805.051 